\title{
Listening for Realism in Charpentier's Louise
}

\author{
FLORA WILLSON
}

\begin{abstract}
On 2 February 1900, Gustave Charpentier's opera Louise premièred at Paris's OpéraComique. Set in contemporary Montmartre, the work was discussed ubiquitously by its earliest critics as réaliste (translatable as both 'realistic' and 'realist') - a tendency that has continued in more recent musicological writing. In this article, I focus on Louise and discourse around it in order to re-examine the complex relationship between opera and realism. After sketching the terms of the opera's reception to assess the case for understanding it as a 'realist' work, I position the opera in relation to theoretical conceptualizations of realism in other art forms. I then present two music examples to explore how Louise might not only resonate with existing understandings of late nineteenth-century French realism, but also expand or disrupt them. Ultimately, this article ponders the possibility that the act of listening might shape its own distinct form of realism.
\end{abstract}

Realism more than almost any other mode of literature makes sight paramount - makes it the dominant sense in our understanding of and relation to the world.

Peter Brooks ${ }^{1}$

On 2 February 1900, a new four-act work, Louise, premièred at the Opéra-Comique in Paris. Its subject, set in contemporary Montmartre, was a love affair between a young seamstress and a bohemian poet. In the immediate run-up to the opera's first performance, as critics debated the operatic suitability of such a topic (and such protagonists), its composer, Gustave Charpentier (a socialist, Prix de Rome winner and long-time resident of Montmartre with a penchant for increasingly outmoded bohemian attire), advertised his attachment to the neighbourhood and its inhabitants in striking terms. 'I love this life that surrounds me,' he told a journalist, 'this life of the street and of the humble; I feel it to be profoundly lyrical.' ${ }^{2}$ In putting working-class Montmartrois on

\section{Email: flora.willson@kcl.ac.uk}

This work was supported by a British Academy postdoctoral research fellowship at King's College London (2015-17), and my research using the Fonds Charpentier at the Bibliothèque Historique de la Ville de Paris was facilitated by the ever helpful Marie-Françoise Garion. For their generous advice, suggestions and encouragement in response to earlier versions of this article, I am also hugely grateful to Charlotte Bentley, Katy Hamilton, Sarah Hibberd, Roger Parker, Ditlev Rindom, Susan Rutherford, Arman Schwartz and Rosie Ward, as well as to the two anonymous readers for this journal. All translations are my own unless otherwise stated.

1 Peter Brooks, Realist Vision (New Haven, CT: Yale University Press, 2005), 3.

2 'J'aime cette vie qui m'entoure, cette vie de la rue et des humbles; je la sens profondément lyrique.' R. D., 'Louise', La presse, 1 February 1900, 2.

(C) The Author(s), 2021. Published by Cambridge University Press on behalf of The Royal Musical Association. This is an Open Access article, distributed under the terms of the Creative Commons Attribution licence (https://creativecommons.org/licenses/by/4.0/), which permits unrestricted re-use, distribution, and reproduction in any medium, provided the original work is properly cited. 
the operatic stage and making them sing, the composer was apparently revealing to Opéra-Comique audiences what he himself could already hear. As he explained, the 'mixture of realism and otherworldly fantasy' offered by his opera was something he thought deeply embedded in the lives of the Parisian working classes. ${ }^{3}$

By the time Louise reached the operatic stage, critics had had several decades to adjust to the once shocking visual realism of painters such as Gustave Courbet and the seeming brutality of literary works such as Gustave Flaubert's Madame Bovary. Even the novels of Émile Zola - his 'naturalist' method understood to have mutated from realism's nastier tendencies, a symptom of what he called 'the need for reality that obsesses us' ${ }^{2}$ - had ceased to attract lurid critical interest. Indeed, Zola had transformed his public image through his involvement in the Dreyfus affair. ${ }^{5}$ Realism had, in other words, begun to lose its revolutionary edge. There was no courtroom drama following Louise's première; rumours of the composer's anarchist leanings - traces of a 'brasserie ibsenism' ('ibsénisme de brasserie') were detected ${ }^{6}$ - failed to prevent the opera from becoming immensely popular with the Opéra-Comique's respectable audience. Five days after the première, additional performance dates were published in response to the huge demand for tickets; ${ }^{7}$ in less than six months the opera had received its fiftieth performance; its five-hundreth came in $1921 .^{8}$

Alongside Louise's lusty popular reception, Charpentier's apparent attempt to incorporate elements identified as réaliste - a term translatable as both 'realistic' and 'realist', and so generating a slippage that will become significant - was widely debated. Some critics, unpersuaded by Charpentier's pre-emptive defence of the working classes as 'profoundly lyrical', reflected on the boundaries of 'the operatic'; many more simply arranged their assessments along an implicit fracture separating aspects that seemed self-evidently realist from those that were conventionally operatic. In sum, all but the briefest responses to Louise in 1900 bear marks of a tussle between the assumed aesthetic affordances of opera - in particular of French opera as produced and consumed at the Opéra and the Opéra-Comique, Paris's two most prestigious houses - and the disruptive tendencies of realism, a category both tethered directly to 'reality' and indexical of existing trends in art and literature.

My focus in this article is precisely on the complex relationship between opera and realism. To be clear: realism has proved a troublesome notion for musicologists - one

3 'Mélange de réalisme et de fantaisie féerique'. 'R. D.', 'Louise'.

4 'Besoin de réalité qui nous tourmente'. Émile Zola, Le naturalisme au théâtre, 2nd edn (Paris: Charpentier, 1889), 84.

5 On Zola's role in the Dreyfus affair, see Priscilla Parkhurst Ferguson, Paris as Revolution: Writing the 19th-Century City (Berkeley, CA: University of California Press, 1994), 213-15.

6 Pierre Lalo, 'La musique', Le temps, 13 February 1900, 1. The term 'ibsénisme' appears in several reviews of Louise's première as a shorthand for contemporary theories promoting free love and anarchism-inflected social change.

7 See the announcement in Le temps, 7 February 1900, 3.

8 Such was the opera's popularity that Charpentier was even admitted in 1912 to the prestigious Institut de France, on what Steven Huebner politely terms 'a relatively slim musical record'. Huebner, 'Between Anarchism and the Box Office: Gustave Charpentier's "Louise", 19th-Century Music, 19 (1995-6), 136-60 (p. 159). A revised version of Huebner's article forms chapters 26-7 of his excellent French Opera at the Fin-de-siècle: Wagnerism, Nationalism, and Style (Oxford: Clarendon Press, 1999); where material appears in both his article and his book, I refer here to the latter. 
rarely theorized in relation to opera or to music more generally. Indeed, in one of the few attempts to conceptualize a specifically musical form of realism, Carl Dahlhaus admitted over three decades ago in Realism in Nineteenth-Century Music that 'whether it is possible to speak meaningfully of realism in respect of music, as it is in respect of literature or the visual arts, is a moot question'? In addressing Charpentier's Louise as a means of returning to such matters, I have been led above all by the language of the opera's reception: few operatic works outside the Italian verismo tradition have been so consistently identified as 'realist', either by early critics or by musicologists. ${ }^{10}$ Put bluntly, the composer's place in standard narratives of opera history has long rested on this aspect of Louise's reputation. ${ }^{11}$ Yet for all that Louise remains exceptional in operatic history, its roots in late nineteenth-century Parisian culture direct us towards a broader intellectual discourse on realism - one that has come chiefly from art history and literary studies, and that has centred above all on figures such as Courbet and Flaubert, Manet and Zola. ${ }^{12}$ In such a context, my principal concern is to examine what Louise might offer these larger discourses within Parisian cultural history. I begin by laying out the basic case for Louise's status as a realist opera, taking my cue from the work's early reception, before discussing the opera's representational dynamics in relation to theoretical conceptualizations of realism in other art forms. I then present two musical examples - neither of which was the object of significant critical attention in 1900 - to explore how Louise might not only resonate with existing understandings of late nineteenth-century French realism, but also ultimately expand or disrupt them. My aim, in short, is to ponder the possibility that the act of listening might (pace Peter Brooks in the epigraph to this article; and pace Dahlhaus in the quotation above) shape its own, distinct form of realism.

\section{Realism by design}

Charpentier's tale of love unfolds against two separate locations in Montmartre: the working-class Faubourg (home to the eponymous heroine and her parents) and the

9 Carl Dahlhaus, Realism in Nineteenth-Century Music (Cambridge: Cambridge University Press, 1985), 10.

10 Bizet's Carmen is perhaps one exception, Verdi's La traviata another; but both have generated significantly larger musicological footprints for other reasons, with the result that 'realism' has never become established as their dominant critical framework or context.

11 As René Leibowitz put it, Charpentier's specifically French take on verismo in Louise assured the opera a 'non-negligible' historical role. Leibowitz, Histoire de l'opéra (Paris: Buchet-Chastel, 1957), 296; quoted in Gustave Charpentier et son temps, ed. Michela Niccolai and Jean-Christophe Branger (SaintEtienne: Publications de l'Université de Saint-Étienne, 2013), 26.

12 The scholarly literature on realism in nineteenth-century literature and visual art is vast. I have found the following particularly stimulating in preparing this article: Linda Nochlin, Realism (London: Penguin, 1971); Michael Fried, Courbet's Realism (Chicago, IL: University of Chicago Press, 1990); Elizabeth Deeds Ermarth, Realism and Consensus in the English Novel: Time, Space, and Narrative, 2nd edn (Edinburgh: Edinburgh University Press, 1998); David Trotter, Cooking with Mud: The Idea of Mess in Nineteenth-Century Art and Fiction (Oxford: Oxford University Press, 2000); Brooks, Realist Vision; Daniel A. Novak, Realism, Photography, and Nineteenth-Century Fiction (Cambridge: Cambridge University Press, 2008); and Fredric Jameson, The Antinomies of Realism (London: Verso, 2013). 
bohemian Butte (the top of the hill) inhabited by her lover, Julien. The first, third and last of the four acts take place in single locations; the second is divided into two tableaux. The action shifts between interior settings - the house where the heroine lives with her parents (Acts 1 and 4); the dressmaker's atelier where she works (Act 2, second tableau) - and outdoor scenes depicting a dawn chorus of street sellers (Act 2, first tableau) and the garden of the lovers' idyll (Act 3), from which the centre of Paris can be seen, twinkling in the distance. These locations were, it seems, meticulously copied: the critic Camille Le Senne was typical when he reported that the opera was staged 'with the most assured and striking realism, without any detail left to chance; the scenery for the crossroads on the Butte, for the rooftop, for the seamstresses' workshop, are astoundingly truthful'. ${ }^{13}$

A similar attitude to representation - and a similarly denotative understanding of 'realism' - is evident in many responses to Charpentier's plot and motley band of working-class characters. A long article by Maurice Emmanuel entitled 'Real Life in Music' offers a clear example. Charpentier, Emmanuel writes,

casts down the puppets of lyric theatre: gods and demi-gods, helmet-wearing heroes, lords and ladies, pretty pages, villagers and shepherds from Watteau, richly brocaded soldiers, gilded Orientals, peasants, gangsters, July Monarchy bourgeois - the entire cast of mannequins and caricatures that the Opéra and Opéra-Comique offer up every night. Instead he raises the curtain on a part of Paris, of Paris such as it really is, to present us with workers, errand boys, street urchins and rag-and-bone men [...] The sanctuary has been desecrated! ${ }^{14}$

Out with the weightily mythological and the piquant picturesque; here, instead, was an identifiable urban setting populated by 'real' people. The decorative, historical or fantastical figures beloved of Paris's two most prestigious operatic venues had been swept aside in favour of the working-class habitués of the city's streets.

Even Charpentier's most determined detractors largely conceded that the opera's representation of its Parisian setting was a success. The Opéra-Comique's director, Albert Carré, and its chief set-painter, Louis Jusseaume, were given much of the credit; and the notion of accuracy - the claim that in this opera Paris could be seen 'as it really is' - was crucial. Although the libretto and stage directions make no mention of exact locations, it was widely accepted that the opera's sets were quasi-photographic reproductions of existing places. Indeed, in the first book-length study of Louise, published only a year after the première, Jules Nordi presented the creative process behind the staging as firmly rooted in Parisian reality:

13 'Louise est montée avec le plus sûr et le plus curieux réalisme, sans qu'aucun détail ait été laissé au hasard; les décors du carrefour de la Butte, de la mansarde, de l'atelier de modes, sont d'une étonnante verité.' Camille Le Senne, 'Premières représentations', Le siècle, 3 February 1900, 2-3 (p. 3).

14 'Il jette bas les fantoches du théâtre lyrique: dieux et demi-dieux, héros casqués, grands seigneurs, belles dames, jolis pages, villageois et bergers Watteau, militaires chamarrés, Orientaux dorés sur tranche, manants, truands, bourgeois 1830 , toute la théorie des mannequins et des grotesques que l'Opéra et l'Opéra-Comique produisent chaque soir. Il lève le rideau sur un coin de Paris, de Paris tel qu'il est, pour nous présenter des ouvriers, des trottins, des gavroches, des chiffonniers [...] Le sanctuaire est profané!' Maurice Emmanuel, 'La vie réelle en musique', La revue de Paris, May-June 1900, 841-83 (p. 843; emphasis added). 
Accompanied by the author and the scene-painter Jusseaume, [Carré] made numerous trips up to the Butte, buying the furniture needed for the interior of a workers' household in the second act from the neighbourhood's dealers, deciding that the set of the same act would depict a spot glimpsed from the rue de la Barre. For his part, the excellent designer Bianchini wandered the Butte of Montmartre at night in pursuit of sketches of rag-andbone men and prowlers. ${ }^{15}$

Nordi's description features two instances of blurring between Charpentier's Paris and that represented on stage: Carré buys furniture from the neighbourhood he plans to depict to use as props; and the set designer's research trips to the Butte sound no less picturesque than the rest of the nocturnal cityscape he portrayed in the opera.

A still more striking overlap emerges from notes preserved in Charpentier's papers. Among the many drafts and sketches for his memoirs held by the Bibliothèque Historique de la Ville de Paris is a sheet labelled 'Mes souvenirs d'étudiant', which lists places in Montmartre, annotated with their significance in Louise. Amid this litany of real Parisian locations with their narrative function glossed ('Rue Lepic', for instance, is the site of 'Louise's abduction, the carriage blinds lowered, driving flat out, the horse on its knees!'), there is one that breaks the pattern: the 'Escalier Ste Marie', Charpentier observes, is 'where I wrote LOUISE'. ${ }^{16}$ This site has no place within the opera itself; but by featuring a location from the narrative of Louise's genesis in a geographical survey of his operatic Montmartre, Charpentier includes himself within the opera's world.

The composer was not alone in hinting at a confusion of urban reality and its artistic representation in Louise. The composer and critic Alfred Bruneau - a few years Charpentier's senior and one of his staunchest supporters - marvelled that the Paris portrayed with such realism in Louise was 'the living, simmering, singing city of Émile Zola's splendid books' ${ }^{17}$ Charpentier, too, claimed to hear the city's song, telling a journalist the day before Louise's première, 'I love this life that surrounds me, this life of the street and of the humble; I feel it to be profoundly lyrical' (see above, note 2) - a choice of words to which I shall return. Altogether more critical, but thinking along

15 'En compagnie de l'auteur et du décorateur Jusseaume, il a fait maintes ascensions sur la Butte, achetant chez les revendeurs du quartier le mobilier nécéssaire à l'intérieur d'un ménage d'ouvriers du second acte, décidant que le décor du mème acte représenterait un endroit aperçu rue de la Barre. De son côté, l'excellent dessinateur Bianchini errait la nuit sur la butte Montmartre, en quête de croquis de chiffonniers et de rôdeurs.' Jules Nordi, Louise de Gustave Charpentier: Notes et impressions (Brussels: Imprimerie Vanbuggenhoudt, 1901), 9. Such a story must belong alongside those told about other composers of this period - Puccini most famously - whose works apparently demanded on-location research where adherence to accepted representational conventions in broad brushstrokes had previously sufficed. For more on Puccini's research into and recreation of a particularly 'Roman' soundscape in Tosca, for instance, see Arman Schwartz, 'Rough Music: Tosca and Verismo Reconsidered', 19th-Century Music, 31 (2007-8), 228-44.

16 'Rue Lepic: L'enlèvement de LOUISE, le fiacre aux stores baissés, en panne, le cheval à terre!'; 'Escalier Ste Marie: Où j'écrivais LOUISE'. Bibliothèque Historique de la Ville de Paris (hereafter BHVP), Fonds Gustave Charpentier, Dossier 22.

17 'Paris, la ville vivante, frémissante et chantante des livres splendides d'Emile Zola'. Alfred Bruneau, La musique française: Rapport sur la musique en France du XIIIe au XXe siècle; La musique à Paris en 1900, au théâtre, au concert, à l'Exposition (Paris, 1901), 156. 
similar lines, the music critics of two mass-circulation dailies, Le petit journal and Le petit Parisien, both diagnosed Louise's plot as belonging to the 'genre Ambigu' (the Théâtre de l'Ambigu-Comique specialized in melodramas and vaudevilles and had recently staged several stage adaptations of Zola's novels). ${ }^{18}$ Most eye-catching of all, in a still more complex layering of mediated realities, Catulle Mendès remarked of the opera's Act 3 love duet that Charpentier's lovers had 'no doubt read and re-read Émile Zola'. ${ }^{19}$

So much for the work's unequivocal rooting in real locations. In each of these cases, Louise's Paris is a city with unmistakable representational pedigree - one recognizable from existing urban depictions already understood (for better or worse) as realist. For Mendès as for Charpentier himself, the fourth wall of the opera's world is distinctly permeable. Just as the composer unwittingly placed himself within Louise's milieu, Mendès imagined Charpentier's characters as Parisian contemporaries who, like everyone else, have been consuming Zola's literary remediations of their urban environment, and who then reproduce behaviour familiar from his novels to bolster the reality-effect of Charpentier's operatic representation of the city. Bruneau, meanwhile, hears Paris singing - but he is again hearing the city portrayed by Zola: always already mediated, always already portrayed as realist.

Few other critics were persuaded by Charpentier's and Bruneau's assertion of Montmartre's vocality. But the arrondissement may nonetheless have lent itself to the peculiar layering of realist representation and supposed reproductions of reality perceived by many. In a scathing profile of Charpentier as a 'vériste français', for instance, Louis Laloy complained that Louise's libretto was 'a Montmartre prose, grubby and vaguely metaphysical, which reeks of the dusty studio, the smoke of old pipes, and wide-brimmed hats proclaiming unimaginable aesthetics' ${ }^{20}$ This particular area of Paris was, in other words, barely real even before it was represented on stage: finde-siècle Montmartre was a place subject to persistent mythologization, one segment of its inhabitants existing in a carefully curated mélange of life and art, fiction and reality. ${ }^{21}$ Laloy nonetheless identified one particular difficulty with Louise's contribution to this emergent, idealized place:

18 See Léon Kerst, 'Premières représentations', Le petit journal, 3 February 1900, 2, and Moncornet, 'Les premières représentations', Le petit Parisien, 3 February 1900, 2. It may be significant that both these authors were writing in mass-circulation dailies aimed at much the same demographic as the dramas staged at the Ambigu-Comique.

19 'Sans nul doute, ils ont lu et relu Emile Zola.' Catulle Mendès, 'Premières représentations', Le journal, 3 February 1900, 2.

20 'C'est une prose de Montmartre, crasseuse et vaguement métaphysique, qui sent l'atelier poussiéreux, la fumée des vieilles pipes, les chapeaux à grands bords affirmateurs d'esthétiques insoupçonnées.' Louis Laloy, 'Le drame musical moderne, III, Les véristes français: Gustave Charpentier', Le mercure musical, 1 July 1905, 169-76 (p. 169). Laloy is one of the few critics who responded to Louise or Charpentier with the term vériste rather than réaliste; the negative usage is significant here, since vérisme was a term usually reserved (as in its English variant) for late nineteenth-century Italian composers, whose music was generally condemned by contemporary Parisian critics.

21 The tension between the bohemian and working-class populations of Montmartre and their respective mores is played out clearly in the opposition of Julien and Louise's parents in Charpentier's opera. The classic scholarly text on the class politics of Parisian bohemianism remains Jerrold Seigel's 
Without a doubt the material details are exact: real scissors pass between the hands of the workers, and the morning papers are folded on news-stand tables just like that. So the leisurely citizen of Dresden or Zurich can marvel, elbowing his neighbour and whispering with a meaningful grin: 'Parisian life! Pariser-Leben!' But this drama of habits and couturiers isn't enough to enchant us, since the author wants to draw only lessons and morals from it, rather than grace or poetry. ${ }^{22}$

For Laloy, the accumulated everyday matter of Charpentier's Montmartre generated an operatic postcard: the image sought by tourists who did not know better, offering nothing of interest (no magic, no art) for a Parisian native. It was too faithful to the claims to 'authenticity' on which the myth of Montmartre rested, too weighed down by its own arguments and proofs.

But the tension that emerges from Laloy's critique - between this opera's obsessive attention to material detail and the art form's long-standing obligation to enchant by transcending and poetically envoicing the material world - is significant, leading us towards the central challenge that Louise posed in 1900. For all that most critics in 1900 deemed Louise's staging an obvious instance of theatrical realism, they were also quick to recognize distinctly non-realist elements elsewhere in the opera. Bruneau saw this hybridity as one of Louise's strengths, describing it as 'at once a work of realism and of dreaming: of outright, aggressive realism in its language, in the exteriority of the drama; of dreaming, hazy and charming, in all that relates to the score'. ${ }^{23}$ The first clause of Bruneau's assessment was echoed by many early critics and is widely quoted in musicological writing on the opera. The division of Charpentier's work into a realist libretto and staging and a dreamlike score is, after all, a conventional parsing of opera's constitutive elements along a realist/idealist axis: music's role is to charm and to bewitch, to elude the mundane precision of an opera's 'exterior', tangible aspects. But such an Orphic cliché grates awkwardly against one of the composer's most widely repeated statements about Louise. In an interview published the week before the première, Charpentier explains why he designates it generically as a 'roman musical':

In the novel there are two distinct sides, drama and description, and in Louise I wanted to have both of these. I have a descriptive part comprising the decor, the scenic milieu and the musical atmosphere in which my characters evolve. And I have the purely dramatic side, given over entirely to the action. It is therefore a real roman musical. ${ }^{24}$

Bohemian Paris: Culture, Politics, and the Boundaries of Bourgeois Life, 1830-1930 (New York: Viking, 1986).

22 'Sans doute les détails matériels sont exacts, ce sont de vrais ciseaux qui passent aux mains des ouvrières, et c'est bien ainsi que l'on plie, sur les tables des kiosques, les journaux du matin. Le paisible citoyen de Dresde ou de Zurich peut alors s'émerveiller, et pousser du coude son voisin en murmurant avec sourire d'allusions: "La vie de Paris! Pariser-Leben!" Mais ces spectacles coutumiers ou couturiers ne suffisent point à nous enchanter, puisque l'auteur ne veut en tirer que des enseignements et des moralités, non de la grâce ou de la poésie.' Laloy, 'Le drame musical moderne, III', 172.

23 'Louise est une œuvre de réalisme et de rêve à la fois: de réalisme franc et violent, quant à la langue, quant à l'extériorité du drame; de rêve imprécis et charmant, en ce qui touche à le partition.' Alfred Bruneau, 'Les théâtres', Le Figaro, 3 February 1900, 4.

24 'Dans un roman il y a deux cotés bien distincts: le drame et la description, et que dans ma Louise j'ai voulu traiter ces deux cotés différents. J'ai une partie descriptive composée du décor, du milieu 
This excerpt makes for strange reading. The notion of 'musical atmosphere' sounds conventional enough, capitalizing on sound's 'hazy' affective powers (to repeat Bruneau). Yet in marked contrast to much nineteenth-century aesthetic thought, Charpentier categorized music as 'descriptive' rather than 'dramatic' - as part of the external scenic 'reality' rather than constituting the opera's implicitly inner drama (to borrow the terminology of a composer notoriously influential on Charpentier). ${ }^{25}$

Elsewhere, though, Charpentier appears more ambivalent about the relationship between the material and the symbolic in his opera. According to a short article published a year after Louise's première, he seems to have experienced frustrations during rehearsals not unlike those of Laloy, the critic who took exception to Louise's unenchanting 'drama of habits and couturiers', weighed down by mundane paraphernalia. As related by the report, Charpentier had instructed his original Mère, Blanche Deschamps-Jehin,

not to bring the soup tureen to the table in the first act in the same way that she would have done it at home. 'It isn't a simple tureen', he said to her, 'which you're bringing from the kitchen and setting down on the table; it's the soup - that is, the end for which the man at work has had to hold out all day. It's the result of that work, it's the substance that sustains life, it's rest, it's intimacy. ${ }^{26}$

Here the composer seems frustrated by the apparent incompatibility between his chosen setting - figured almost automatically as realist by critics - and conventional modes of dramatic representation. Although Charpentier made the radical move of putting a recognizably working-class milieu on the operatic stage, he also wanted to imbue that milieu with symbolic significance. Everyday soup delivery was insufficiently meaningful. Instead, the soup tureen needed to be understood as an object invested with both denotative and symbolic importance - one referring indexically to the material trappings of contemporary Parisian life while simultaneously functioning as

scènique et de l'atmosphère musicale dans laquelle vont évoluer mes personnages. Puis j'ai la partie purement dramatique, consacrée entièrement à l'action. C'est donc bien un véritable roman musical.' Gustave Charpentier, quoted in F. de Ménil, 'Gustave Charpentier', La vie théatrale, 28 January 1900, 30-2 (pp. 30-1; emphasis original); translation slightly modified from that of Huebner in his French Opera at the Fin-de-siècle, 443.

25 For more on Wagner's impact on Charpentier, see Huebner's detailed discussion in chapters 26-7 of his French Opera at the Fin-de-siècle. Charpentier's conceptualization of his opera as a 'roman musical' seems to have had a considerable impact on Dahlhaus, who enthusiastically took up the composer's pseudo-Wagnerian terms to see the modern urban milieu, not the human characters, as Louise's true protagonist, claiming that, "Instead of a close-knit structure of "actions" which interlock in such a way as to bring about the tragic outcome, the "musical novel" is formed from a loose-knit series of "tableaux", and the "milieu", instead of merely serving as a background to the action seen on the stage, advances to the footlights and plays a quasi-active role in the drama.' Dahlhaus, Realism in Nineteenth-Century Music, 93.

26 'Gustave Charpentier, lors des répétitions de Louise, recommandait bien à Mme. Deschamps-Jehin de ne pas apporter au premier acte la soupière sur la table de la même façon dont elle aurait pu le faire chez elle. "Ce n'est pas une simple soupière, lui disait-il, que vous apportez de la cuisine et déposez sur la table, c'est la soupe, c'est-à-dire le but vers lequel a du tendre, toute la journée, l'homme au travail. C'est le résultat de ce travail, c'est la substance dont s'entretient la vie, c'est le repos, c'est l'intimité."' 'Divers', Le national, 18 February 1901. A handwritten transcription of this report appears among Charpentier's papers; see BHVP, Fonds Gustave Charpentier, Dossier $24 \mathrm{~b}$. 
Charpentier's answer to the magical, meaning-saturated paraphernalia scattered through the altogether less quotidian worlds of Wagner: sword, potion, helmet, fire.

To be clear, Charpentier's advertised aims in Louise were not only ambitious, they were in danger of appearing internally at loggerheads. The problem for many critics in 1900 was ultimately neither that Charpentier wanted to put working-class Paris on the operatic stage, nor that his operatic representation of the city appeared 'at once a work of realism and of dreaming'. Put simply (and despite the composer's claim that Parisian life was itself 'lyrical'), the real difficulty was that Louise's numerous realist traces were judged unsuitable for, if not antithetical to, operatic treatment. One critic noted how Louise's mother 'ironed her laundry, lit her stove, tasted and seasoned her soup'. He insisted that he was not shocked, but nevertheless pondered, 'Was it necessary, and why seek to introduce into music, the idealist art form par excellence, an almost impossible realism?' 27 Another observed that one could find more diverting tales of everyday life in a newspaper, before questioning the 'musicabilite' of such stories. ${ }^{28}$ The same apparent incompatibility played out in reverse in relation to Charpentier's chorus of street cries in the first tableau of Act 2. As heard by Pierre Lalo (one of the opera's more aggressive early critics), these 'rigorously exact imitations of the songs that they sing on the Butte of Montmartre' were 'almost deprived of art and of true music'. ${ }^{29}$ Once pressed into the service of 'realist' representation, such sonic 'found objects' were stripped of their very identity as music. Most damning of all was Léon Kerst, who acknowledged Charpentier's desire to take his protagonists 'from the gutter of Montmartre' ('les bas-fonds de Montmartre') but pointed out a fundamental flaw: 'He makes them speak a language that isn't theirs [...] and he makes them sing music that will never be theirs. I conclude from this that in this theatre that claims to be true, real, even realist, there is more accumulated falsity than in any other.' 30 The problem for Kerst, as for many others, was not Charpentier's realist depiction of Paris; it was the fact that that depiction was operatic - that his supposedly 'real' characters sang.

\section{Noises off}

The argument that condemned Charpentier's operatic voices as forever non-realist was predicated on a widespread assumption that realist representation must also be realistic, must outwardly resemble phenomena in the real world. As the argument went, in finde-siècle Paris the working classes do not actually sing instead of speaking; thus, an

27 'Mme. Deschamps-Jehin repasse son linge, allume son fourneau, goûte et assaisonne son potage [...] Non, tout cela n'a pas choqué, mais était-ce bien utile, et pourquoi vouloir introduire dans la musique, art idéaliste par excellence, un réalisme presque impossible?' Robert Gangnat, 'Les premières', Le matin, 3 February 1900, 4.

28 Pierre Kunc, 'A propos de Louise', Le feu follet, May 1900, 273-8 (p. 276).

29 'Tels autres encore, presque dépourvus d'art et de musique veritable, sont des imitations rigoureusement exactes des chansons que l'on chante sur la Butte Montmartre.' Lalo, 'La musique', 2.

30 'Il leur fait parler une langue qui n'est pas la leur, [et] il leur fait chanter une musique qui ne sera jamais la leur. J'en conclus que dans ce théâtre qui prétend être vrai, réel, même réaliste, il y a plus de faussetés accumulées que dans n'importe quel autre.' Kerst, 'Premières représentations'. 
opera in which they sing as a matter of course cannot be realist. This elision between the realist and the realistic underlies much of Louise's critical discourse as a whole. The conceptual challenge that such an elision poses is only exacerbated by the fact that, as mentioned earlier, the French term réaliste can mean both realistic and realist - where the latter term, in contrast to the former, refers specifically to a historical, minutely theorized representational mode rather than to the resemblance to (or even incorporation of physical objects from) the material world. To compound these elisions and slippages, numerous academic theorizations of realism in recent decades have exclusively concerned literature and visual art, making no attempt to account for historical arguments about the possibility of a specifically operatic realism.

Such academic theorizations beyond musicology have consistently identified realism with an assemblage of connected attributes: its conception of the relationship between representation and reality that typically entails a heightened sense of contemporaneity or otherwise self-conscious stance towards the present, for instance. (Not for nothing did Zola label Monet, Renoir and Bazille at the 1868 Salon as 'Les Actualistes'.) What is more, realism is generally understood as urban and rooted in the affective world of 'modernity'; and it usually emerges from a left-wing political position. In terms of these characteristics, one might easily suture Louise - perhaps, by extension, opera as a whole - into the prevailing definition of realism established by scholars of other art forms. ${ }^{31}$ Yet other aspects of that emergent definition are more problematic. What is the opera scholar to make, for instance, of Brooks's forceful declaration in his 2005 book Realist Vision that realism 'more than almost any other mode of literature makes sight paramount'? Or of Linda Nochlin's subtler conviction that realism aimed 'to give a truthful, objective and impartial representation of the real world'?32 Must realism be understood only in terms of the old cliché of modernity as a primarily visual phenomenon - or might there be space for sound to complicate and enrich it, in this case for opera to shape its own distinct form of realism without simply ceasing to be operatic?

There are still more knots to unpick. While most critics describing Louise's staging or setting as réaliste around 1900 offered it as a closing compliment to the work's creators, the term had almost uniformly negative associations in relation to Louise's music.

31 Such a suture would have considerable aesthetic pedigree: in 1893, Zola himself wrote a journalistic manifesto for a new brand of opera - 'drame lyrique' - which he argued should entail a 'clearly drawn setting and living characters' ('un milieu nettement indiqué et des personnages vivants'), ultimately foregrounding 'a more directly human drama [...] resounding between us, poor humans, in the reality of our troubles and our joys [...] You can dress it up in velvet if you want; but make sure there are humans inside and that the whole work gives out a deep cry of humanity' ('un drame plus directement humain [...] éclatant entre nous, pauvres hommes, dans la réalité de nos misères et de nos joies [...] On peut l'habiller de velours si l'on veut; mais qu'il y ait des hommes dedans, et que toute l'œuvre sorte un cri profond d'humanité'). Émile Zola, 'Le drame lyrique', Le journal, 22 November 1893, 1. We should note that, like so much later writing on operatic realism, Zola focuses here on the non-musical aspects of 'drame lyrique'; music's role, he explains, is solely to 'provide commentary and to elaborate' ('de commenter et de developper'). For more on Zola's views on a specifically operatic naturalism, see Georges Favre, Musique et naturalisme: Alfred Bruneau et Emile Zola (Paris: La pensée universelle, 1982).

32 Linda Nochlin, Realism (London: Penguin, 1971), 13. 
A sympathetic profile of Charpentier by Maurice Le Blond published immediately after the première makes this clear:

It's no longer Walhalla that [Charpentier] evokes; it's no longer allegorical, mythical, legendary people to whom he gives expression. Instead, it's the landscapes of daily life whose atmosphere he recreates; the feelings, instincts and desires of true men and true women that he translates. ${ }^{33}$

For Le Blond, Charpentier's embrace of 'la vie quotidienne' was a positive, productive renunciation of Wagnerian influence in favour of French truth; the term réalisme tellingly appears only once, later in the profile, within a warning that the composer will be criticized by 'certain excessive Wagnerians' for 'the realism of his motifs'. ${ }^{34}$ Sure enough, ten days after Le Blond's article, Lalo complained that some of Charpentier's vocal lines were copied so exactly from music sung on the Butte that they barely constituted music at all. In a similar vein, albeit largely pro-Charpentier, another critic maintained that, 'The staging of modern life in music drama can be an obstacle to the free outpouring of lyrical ideas. Material struggles and faits divers will never belong in the musical domain. ${ }^{35}$ In each case, the supposed realism of Louise is derived from the opera's incorporation of material objects borrowed from real life.

Uniquely among Louise's early critics, Emmanuel attempted to distinguish between the opera's use of realistic elements and its putative nature as a 'realist' opera. (He was presumably aided by the unusual length of his article and the months that had elapsed between the première and the publication of his response.) Having sketched a short history of realism in opera (starting at Rousseau's Le devin du village and taking in $L a$ traviata, Siegfried(!), Die Meistersinger, Carmen and three of Bruneau's operas), Emmanuel insisted:

Don't be mistaken: if Charpentier's Louise offers, at times, admirable examples - perhaps the first real models, in the theatre - of real life in music, it is by no means an entirely realist work. Far from it: convention abounds in it. ${ }^{36}$

In its historiographical intentions and consideration of what 'realism' might constitute beyond objects and locations imported from reality into the alternative universe of the operatic stage, Emmanuel's assessment reads like a surprisingly modern interpretation of Louise. His distinction between the representation of real life and a representative

33 'Ce ne sont plus les Walhalla qu'il évoque, ce ne sont plus des personnages allégoriques, mythiques, légendaires, qu'il fait s'exprimer. Mais, ce sont des paysages de la vie quotidienne dont il reconstitue l'atmosphère, de vrais hommes et de vraies femmes dont il traduit les sentiments, les instincts, les frissons.' Maurice Le Blond, 'Types d'aujourd'hui: Gustave Charpentier', La presse, 3 February $1900,3$.

34 'Je sais bien que certains wagnériens excessifs [...] ne manqueront pas de reproche à Charpentier le choix de ses sujets, le réalisme de ses motifs.' Ibid.

35 'La mise en scène de la vie moderne dans le drame musical, peut être un obstacle à la libre explosion des idées lyriques. Les besognes matérielles, les faits divers, ne seront jamais du domaine musical.' Robert Brussel, 'Chronique musicale', La revue d'art dramatique, March 1900, 272-82 (p. 281).

36 'Il faut pas s'y tromper: si la Louise de M. Charpentier fournit par instants d'admirables exemples et peut-être les premiers modèles vrais, au théâtre, de la vie réelle en musique, elle n'est point une œuvre toute réaliste. Tant s'en faut: la convention y surabonde.' Emmanuel, 'La vie réelle en musique', 857. 
mode or attitude that we might call 'realist' is, in particular, rare in nineteenth-century writing on realism in any medium. For although, as the literary scholar Christopher Prendergast observes, that age saw 'the flowering of realism as a set of literary pictorial practices', it was not the moment of its 'sophisticated conceptual articulation' ${ }^{37}$ The latter has largely been located in and following the final decades of the twentieth century, with scholars such as Sandy Petrey observing that 'the dilemmas of representation' are themselves crucial narrative subjects in realism. ${ }^{38}$ Far from reading realist fiction as representative of an external reality, that is, Petrey is concerned with how an illusion of reality - with its modes and mechanisms of representation - has been generated.

For Alison Byerly, a solution to the difficulty of evoking reality through art 'while acknowledging its difference from the real world' is found in references both to the arts in general and to individual, specific artworks; and such gestures are embedded in the narratives of numerous realist novels. ${ }^{39}$ Yet underpinning any of these intermedial references is another significant characteristic of realism as it has been shaped by recent theorists: a tension between realism's preoccupation with quotidian materiality and its gestures towards and inevitable dialogue with the ideal and the imaginary. One erstwhile éminence grise of literary studies, Northrop Frye, was undoubtedly writing at a low point in realism's critical currency when he dismissed it in 1957 as 'an art of implied simile' to be measured unfavourably against myth's 'art of implied metaphorical identity' ${ }^{40}$ But even Frye's passing comment (realism being otherwise absent from his Anatomy of Criticism) locates realism's significance in its bridging of the gap between a phenomenon experienced in the physical world or a truth internally felt and what may be re-presented in language; as he put it, 'Realism, or the art of verisimilitude, evokes the response "How like that is to what we know!"” 41 Much more recently but in a related vein, the art historian James D. Herbert has found in Courbet's late works what he calls the artist's 'predilection for matching world to canvas' - his subjects chosen according to 'those aspects of the world that physically resemble his paints' ${ }^{42}$

The rhetoric of resemblance is important here: it should remind us that realism has been characterized not only by traits proper to the construction of individual artworks or centred on the attitude of their creators, but also by its modes of consumption - even

37 Christopher Prendergast, 'Introduction: Realism, God's Secret, and the Body', Spectacles of Realism: Gender, Body, Genre, ed. Margaret Cohen and Christopher Prendergast (Minneapolis, MN: University of Minnesota Press, 1995), 1-10 (p. 2).

38 Sandy Petrey, Realism and Revolution: Balzac, Stendhal, Zola, and the Performances of History (Ithaca, NY: Cornell University Press, 1988), 1.

39 Alison Byerly, Realism, Representation, and the Arts in Nineteenth-Century Literature (Cambridge: Cambridge University Press, 1997), 2.

40 Northrop Frye, The Anatomy of Criticism: Four Essays (Princeton, NJ: Princeton University Press, 1957; repr. London: Penguin, 1990), 136. Steven Huebner draws on Frye's distinction between realism and myth in Huebner, 'Naturalism and Supernaturalism in Alfred Bruneau's Le rêve', Cambridge Opera Journal, 11 (1999), 77-101 (p. 78).

41 Frye, The Anatomy of Criticism, 136.

42 James D. Herbert, 'Courbet, Incommensurate and Emergent', Critical Inquiry, 40 (2014), 339-81 (p. 351). 
by new types of 'reading' demanded by realist texts. Hence the art historian Michael Fried bemoans the fact that realist paintings have generally been looked at 'less intensively', since discussion has 'tended to proceed on the unexamined assumption that a realist painter's representation of a given scene was to all intents and purposes determined by the "actual" scene itself' and thus close scrutiny has been felt to be 'beside the point'. ${ }^{43}$ More recently, aspects of realist prose have been co-opted into debates about the notion of 'surface reading': Elaine Freedgood and Cannon Schmitt observe (with tongue only partly in cheek) that, 'We do not use Heart of Darkness as a sailing manual or a handbook for the extraction of natural resources from colonized places. ${ }^{44}$ Their point is to demonstrate the extent to which we have learnt to pass over language assumed to be too 'denotative', 'technical' or 'literal' to be of literary interest.

It is no coincidence that while musical texts have similarly been deemed technical (and thus largely off limits for discussion elsewhere in the humanities), they have also been assumed to be generally incapable of either denotation or literalness: both important manifestations of realist representation in nineteenth-century literary texts. The questions of musical meaning that threaten to emerge here are long-standing and unresolved, and they inevitably reach far beyond the scope of this article. But it is nevertheless important to note once more that, in the context of a sophisticated and sustained theoretical engagement with realism in literary and visual studies, musical works have gone largely unexamined and musicology itself has had little to say. In the case of Louise (whose composer's effusions, reception history and setting alike might well suggest comparisons with the contemporary novels of Zola, for instance, or with the visual language of later nineteenth-century French art), scholarly writing has concentrated for the most part on other aspects: its references to contemporary anarchism, for instance; its indebtedness to Wagner; its advocacy of social change; or its contexts in fin-de-siècle French culture, politics and society. ${ }^{45}$ Most recently, the advocacy of the musicologist Michela Niccolai has catalysed something like a new subfield of Charpentier studies in which Louise sits as a crucial piece of evidence in the argument for the composer's long-overlooked significance in and contribution to late nineteenth-century French musical culture. ${ }^{46}$ In all of this work, persuasive arguments

43 Fried, Courbet's Realism, 3.

44 Elaine Freedgood and Cannon Schmitt, 'Denotatively, Technically, Literally', Representations, 125 (2014), 1-14 (p. 1).

45 Important contributions to this historicizing tendency include Jane F. Fulcher's excavation of the opera's possible contexts and meanings in the aftermath of the Dreyfus affair, 'Charpentier's Operatic "Roman musical" as Read in the Wake of the Dreyfus Affair', 19th-Century Music, 16 (1992-3), 161-80; Giuseppe Montemagno's comparative work on Louise and its near-contemporary Pelléas et Mélisande in 'Chambres avec vue: Regards croisés sur Louise et Pelléas et Mélisande', Gustave Charpentier et son temps, ed. Niccolai and Branger, 227-65; and, above all, Steven Huebner's valuable investigation into Louise's composition and production against the twin backdrops of Wagnerism and anarchism - an investigation that remains the most subtle, in-depth study of the opera in English - in his 'Between Anarchism and the Box Office'.

46 See in particular Michela Niccolai, La dramaturgie de Gustave Charpentier (Brepols: Turnhout, 2011), esp. (on Louise) pp. 149-272. Elsewhere, building on Huebner's work on Charpentier's relationship to Wagner, Niccolai's chapter 'Les maîtres chanteurs à l'origine du naturalisme français? L'exemple d'Alfred Bruneau et de Gustave Charpentier' in The Legacy of Richard Wagner: Convergences and Dissonances in 
have been made for Louise's distinctiveness within Parisian cultural history at the fin de siècle - in particular for its historiographical significance despite its position on the fringes of the modern operatic canon.

Louise's music has nonetheless proved difficult to incorporate into arguments for taking the opera seriously. ${ }^{47}$ The principal challenge is that many of Louise's most striking musical aspects seem to emphasize a lack of sophistication: its sub-Wagnerian motivic surface, for instance, has spawned a long-running series of attempts to locate and name individual 'leitmotifs' and to chart their development. ${ }^{48}$ The composer's novel importation of a sewing machine into the seamstresses' scene is, for all its striking literalness, noted by commentators but not subjected to further enquiry. ${ }^{49}$ References to the opera's early-morning street scene with its chorus of street cries have sometimes missed the irony that by the late nineteenth century such cries were widely anthologized but also bemoaned as 'lost', heard more regularly on the Parisian stage than on the city's thoroughfares. ${ }^{50}$ The fuller significance of such a nostalgic gesture - more sonic lieu de mémoire than sound object - surely lies in its contribution to what Huebner terms Louise's 'significant role in the canning of Montmartre in the century to come'. ${ }^{51}$

Aesthetics and Reception, ed. Luca Sala (Brepols: Turnhout, 2012), 185-202, argues that 'the shadow of Die Meistersinger' (p. 198) can be detected at various points in Louise and ponders whether Wagner may have precipitated in Charpentier a new 'musical and social awareness' as he did in Alfred Bruneau, whose operatic naturalism in Le rêve Niccolai traces back to the influence of Wagner's final opera (p. 201).

47 Indeed, as a reminder of how easily the opera and its composer could be dismissed as trivial in the high-modernist criticism of the mid-twentieth century, we might turn to Martin Cooper, who described Charpentier as having 'neither taste nor distinction' though 'he had a certain sort of personality' before summarizing Louise as 'a cross between the middle-class comédie larmoyante of the eighteenth century and a sentimental defence of the gospel of Free Love, set against a pretentious mystical background of Paris, envisaged as a kind of idol to whom Louise is sacrificed'. Cooper, French Music from the Death of Berlioz to the Death of Fauré (London: Oxford University Press, 1951), $110-11$.

48 The earliest sustained attempt to do so was by André Himonet, in Louise de G. Charpentier: Étude historique et critique: Analyse musicale (Paris: P. Mellottée, [1922]), who appeared to enjoy the collaboration of Charpentier himself; numerous notes and observations about individual motifs and their significance may be found among the composer's papers. See BHVP, Fonds Gustave Charpentier, esp. Dossiers 22-3. More recently, Manfred Kelkel has returned to Charpentier's employment of 'motifs conducteurs' as they epitomize one musical characteristic of his conception of naturalist opera. See Kelkel, Naturalisme, vérisme et réalisme dans l'opéra de 1890 à 1930 (Paris: J. Vrin, 1984), 292-300.

49 Huebner is again an exception here, observing Charpentier's own comparison of the scene to Das Rheingold's Nibelheim - the latter's anvils downsized for this altogether more feminine setting. See Huebner, French Opera at the Fin-de-siècle, 444.

50 Indeed, by the late nineteenth century, street cries in Paris and various other European cities (London in particular) had become the focus of a small self-reflexive industry bent on charting and celebrating their history. Once again, Huebner is unusual in addressing the historical complexity in evidence here: the presence of these cries in an opera in 1900 cannot be adequately explained, pace Aimée Boutin, by either 'sound realism' or the vaguer possibilities of 'musical and symbolic motifs'. See Huebner, French Opera at the Fin-de-siècle, 466-7, and Aimée Boutin, City of Noise: Sound and Nineteenth-Century Paris (Urbana, IL: University of Illinois Press, 2015), 40.

51 Huebner, French Opera at the Fin-de-siècle, 466. My use of the term lieu de mémoire is borrowed from Pierre Nora's famous theorization of how particular 'sites' of and for memory are constructed for political ends. See Nora, Les lieux de mémoire, 3 vols., rev. edn (Paris: Gallimard, 1997); trans. as 
This is not to say that the term 'realism' has not previously been used in relation to Louise. On the contrary, the term appears regularly both in musicological studies and in opera histories more generally. ${ }^{52}$ The problem is, however, that the nineteenth-century tendency to elide what I earlier defined as the realist and the realistic has persisted. What is more, aspects of the opera that have been labelled 'realist' - whether in 1900 or more recently - have generally earned the epithet via more or less explicit measurement against the standard attributes of realism in other art forms and other fields of academic endeavour. ${ }^{53}$ The very notion of realism in opera, that is, has seemed largely predicated on any given work's capacity to demonstrate characteristics expected of literary or visual realism - to respond to a different medium's array of generic features, expectations and conventions. But, to repeat the question, what might be musically significant in an instance of putative operatic realism? What might be particular to operatic engagement with everyday life and what could opera and its voices offer to realist representation? The move towards some answers might begin with the observation by Louise's early critics that the operatic voice was often heard as out of place - displaced in its own medium. Kerst, after all, condemned Charpentier's singing workers as fundamentally false, their lyricism as fakery committed amid the realism of their surroundings. Let us continue, then, by considering one of the opera's rare moments of self-conscious 'staging' of the voice.

Realms of Memory: Rethinking the French Past, 3 vols. (New York: Columbia University Press, 1996$8)$.

52 Major studies that discuss Louise in terms of realism include those by Huebner, whose two chapters on Louise in French Opera at the Fin de siècle appear within a section explicitly entitled 'Realist Opera' (pp. 395-467), and Niccolai, who follows the opera's earliest critics in referring to its setting and scenery as 'realist', but explains that she uses the term "'réalisme" musical' to refer specifically to 'sons tirés de la réalité' (that is, references in the opera to real music, which would have been recognizable to listeners in 1900), thus following a long-standing association between the incorporation of existing objects from the physical world and realist representation (see Niccolai, La dramaturgie de Gustave Charpentier, 267 n. 494). An article by Andreas Giger demonstrates that similar complexities and confusions emerge in the larger body of writing on operatic verismo, and thus that the established negative definition of operatic realism or naturalism as separate from its Italian counterpart does little to clarify matters. See Giger, 'Verismo: Origin, Corruption, and Redemption of an Operatic Term', Journal of the American Musicological Society, 60 (2007), 271-316. As Serge Gut noted in his preface to Kelkel's book-length study of all three concepts, it is extremely difficult to unpick the differences between naturalism, verismo and realism. Gut, 'Préface', in Kelkel, Naturalisme, vérisme et réalisme, 35 (p. 3). Kelkel's investigation itself still offers a thought-provoking catalogue of what a combined 'repertoire' might look like - but it nonetheless relies on largely unspoken and unexamined differences between the three terms.

53 Kelkel offers a partial exception to this rule, since he examines the shared musical characteristics of the corpus of works he has assembled and names them the chief musical characteristics of realist opera. Unfortunately, however, the very works which he assumes a priori to be realist are judged to be so on the basis of their plots - which is to say on the basis of their compliance with the tenets of French literary realism of the later nineteenth century. Another (in some ways more productive) exception is presented by Adriana Guarnieri Corazzol's 1993 article on opera and verismo, which identifies a set of musical features common to verismo operas, a body of works gathered together on the basis of their emergence during what Corazzol calls 'the verismo period' in opera, identified as 1890-1910. Corazzol nevertheless remains focused explicitly on Italian opera rather than French repertoire or the art form more generally; see her 'Opera and Verismo: Regressive Points of View and the Artifice of Alienation', Cambridge Opera Journal, 5 (1993), 39-53, esp. pp. 40-1. 


\section{Voice}

The second tableau of Act 2 of Louise is set in the couturier's at which the heroine works. According to Carré's staging directions for the première, the curtain should rise on a chorus of female workers (Louise among them) arrayed carefully amid mannequins, sewing tables and other professional paraphernalia. The women are instructed to 'work while chattering - Some sing - One labourer works at a machine'. ${ }^{54}$ The scene continues with two sonic intrusions from outside: a short, chaotic polka from an unseen band of musicians; and then a longer lover's serenade (complete with guitar accompaniment) by their ringleader, Julien. At first the women are charmed by the song, offering admiring commentary. But when it takes a tragic turn (its purpose, we discover, is to persuade Louise to elope with him, since her parents forbid their marriage), they lose interest, becoming increasingly irritated. Eventually they drown him out with calls for 'Music!' and a return to the polka with which the scene began, now transformed into a cancan.

Little of Charpentier's score was subject to close scrutiny by early critics, but a few passing comments are revealing. For Gaston Serpette, the scene conveyed 'in real-life music the flow of dialogue of 20 or so labourers who work while chattering'; $55 \mathrm{Le}$ ménestrel congratulated the composer on the 'charming dexterity' of his score, 'which seems to make light of the difficulty of making a dozen noisy girls babble away together or in turn' ${ }^{56}$ and the ultra-Wagnerian Mendès pointed to the scene as one in which Charpentier had defied the temptations of 'the fantastic' ('le fantastique') to remain focused on 'coarse realities' ('les réalités vulgaires'). He also praised the scene's 'true miracle of choral and orchestral design, from which the song of the wandering singer emerges for the pleasure of the grisettes'. ${ }^{57}$

Each of these comments elides conventional operatic modes of representation with what is being represented. Serpette labels the opening profusion of melodic dialogue exchanged between the workers as 'real music' ('musique réelle') and thus, by implication, as unusually close to 'real' chattering, despite the fact that such declamation had by the end of the nineteenth century largely replaced more formal recitative as a standard feature of new operas. Le ménestrel's blurring of compositional dexterity and the challenge of policing noisy young women is still more striking: the critic seems determined to maintain and even extend the operatic fiction, implying that the female chorus on stage are themselves grisettes and thus sonically hard to manage, despite their training as professional vocal impersonators. Mendès makes a similar rhetorical move.

54 'Les ouvrières travaillent en caquetant - Quelqu'unes chantent - Une ouvrière travaille à la machine.' Louise: Mise en scène de M. Albert Carré rédigée par M. Bertin (Paris: Au ménestrel, Heugel \& Cie, [1900?]), 43. BHVP, Fonds Gustave Charpentier, Dossier 40.

55 'Le deuxième tableau, l'atelier de couture, où le musicien exprime, en musique réelle, le mouvement du dialogue d'une vingtaine d'ouvrières qui travaillent en caquettant'. Gaston Serpette, 'Premières représentations', Gil Blas, 3 February 1900, 4.

56 'Une dextérité charmante, qui semble se jouer des difficultés de faire babiller ensemble ou tour à tour une dizaine de fillettes fortes'. H. Moreno, 'Semaine théâtrale', Le ménestrel, 10 February 1900, 35.

57 'Véritable prodige d'agencement choral et orchestral - d'où se détache, pour le plaisir des grisettes, la chanson de chanteur ambulant'. Mendès, 'Premières représentations', 2. 
As he slides from Charpentier's skilful construction of the scene's texture to an inferred fictional motivation for Julien's serenade, he seems to imply, bizarrely, that Charpentier arranged the scene as he did for the pleasure of the onstage female listeners.

But perhaps bizarre is too strong a word. Mendès's suggestion is not far removed from the rhetoric produced during a moment in later twentieth-century opera scholarship, when the musicologist Edward T. Cone and the philosopher Peter Kivy pondered the boundaries of 'the world of opera and its inhabitants' (to revive Cone's phrase). ${ }^{58}$ Both Cone and Kivy were concerned with the meaning and ontological status of operatic singing - the question of whose music an opera audience believes it is listening to when attending to a particular character; the question of when singing sounds like singing and when it sounds like speaking; the question, ultimately, of how one might justify formal musical conventions within the fictional world of an opera. Their work laid important groundwork for any later consideration of operatic realism. For my purposes here, though, the most productive aspect is the centrality of the notion of diegetic music - music heard as music on stage, within the fictional world of the opera. ${ }^{59}$

The passage from Louise which I have just discussed unfolds, after all, as a short series of diegetic 'moments': as the curtain rises, some of the workers are described as singing as well as chattering; and both the stage band's dance tune and Julien's offstage serenade are long-established operatic tropes of staged performance. Yet the serenade is, in this particular case, by no means stable qua performance. It falls into four verses, the first two of which are musically very similar, each featuring the tenor voice accompanied only by highly conventional figures on the guitar. These verses are framed by the female chorus - placed, unusually, in the position of listeners commenting on an evidently seductive voice-object - and with bursts of orchestral sumptuousness to drive the point home. ${ }^{60}$

The most revealing moment, however, is the point at which the diegesis dissolves. The last two verses of Julien's serenade mark his increasing agitation: the allegorical

58 See, above all, Edward T. Cone, 'The World of Opera and its Inhabitants', Music: A View from Delft, ed. Robert P. Morgan (Chicago, IL: University of Chicago Press, 1989), 125-38, which subsequently provoked a response from Peter Kivy: 'Opera Talk: A Philosophical "Phantasie", Cambridge Opera Journal, 3 (1991), 63-77. David Rosen then produced the most widely discussed of several high-profile responses to both previous essays, in his 'Cone's and Kivy's "World of Opera", Cambridge Opera Journal, 4 (1992), 61-74.

59 An enormously influential alternative approach to the meanings of operatic diegesis can be found in Carolyn Abbate's groundbreaking study Unsung Voices: Opera and Musical Narrative in the Nineteenth Century (Princeton, NJ: Princeton University Press, 1991), which sketches and investigates what Abbate terms 'an aural vision of music animated by multiple, decentered voices localized in several invisible bodies' (p. 13). Stimulating as it could be to ponder the place of such decentred voices and invisible bodies in the context of putatively realist opera, my project in this article is rather more literal-minded, being concerned with the sounds emanating from and indexical of bodies on stage animate and inanimate - that are, if anything, all too visible.

60 Their second intervention is highly redolent of Carmen's opening, in which a male chorus fantasizes about and subsequently provides running commentary on the emergence of the factory women from work, but with the gender roles reversed. The quasi-orgasmic climax of the women's second intervention in Louise makes abundantly clear, however, that female listening can easily do double duty as erotic in its own right. 
love story turns sour; the guitar has some violent strumming and then disappears altogether, replaced by an orchestral accompaniment of pizzicato strings, growling woodwind and percussion. Julien's vocal line abandons the conventional contours of a serenade and becomes ever less simply melodic - ever more Wagnerian, in fact, its shape driven by increasing harmonic adventurousness. But the female commentary on Julien's singing does not stop. Instead, it becomes progressively entangled with it in a single, complex texture, far from the careful division of song and commentary in the first two verses. These choral contributions, having previously been markers of vocal femininity (legato lines, sighing motifs and simple harmonies encased within lush string textures), become ever less tuneful, breaking down twice into notated cackling as the workers declare themselves irritated by Julien's new musical mode.

What might this breakdown of stage performance suggest about opera's relationship to nineteenth-century realism? Recall Herbert writing on Courbet, in particular the idea that realist artists selected their subject matter on the basis of its material proximity to their medium: that waves are not so different from liquid paint; that an obsession with strong vertical lines and objects might have something to do with the fact that paintings themselves, once hung, constitute vertical surfaces. It would be straightforward to build on Herbert's line of thought here: composers interested in the possibilities of realist representation in opera, as Charpentier was, have repeatedly been drawn to subjects entailing musical performance (think of Carmen, or of many verismo operas). To return to an earlier distinction, there is little question that some of the most realistic musical moments in opera are those involving diegetic singing. In those passages, the potentially alienating (or enchanting) disjunction between the world of opera and our own is drastically reduced. But what of the realist, not merely the realistic?

I have already insisted that if realism is to have serious purchase on late nineteenthcentury opera, its definition cannot be simply inferred from existing conceptions of the term in other art forms. Yet Julien's Act 2 serenade can suggest another way. It begins unequivocally as realistic and adheres initially to the conventional generic expectations of such a number. But the serenade's gradual transition away from those conventions a transition traced by the altogether less clearly diegetic commentary of the female labourers - is more unusual. One important marker of the serenade's shift from diegesis to non-diegesis is the replacement of the Italianate guitar with striking, perhaps even Wagnerian, orchestration. The latter cannot be part of the opera's fictional world, as the guitar was; indeed, it seems to have become unmoored from Julien's voice. The women are still listening to him sing, albeit with significantly less pleasure; and the kind of vocal writing Charpentier provided for Julien in the second half of this serenade is not simply a return to his own melodic norm, rather, it seems to gesture towards another model of operatic vocality - that of the unendliche Melodie still feared and despised by Wagner's most polemical detractors, which acts here as an auditory index of the overwrought, the emotionally undisciplined, even the unmusical.

In composing out the disintegration of a moment of vocal diegesis, Charpentier allows us to explore the blurring of two modes of operatic vocality: marked stage-song and unmarked singing-as-speech. But he also presents a significant shift between two 
operatic conventions, from the lover's realistic serenade to the semiotic overlay afforded by musical quotation and paraphrase. Taking our cue from such an affordance, we might hear the operatic voice as having its own semantic reality: its own multiple voices that it can ventriloquize; its own compositional found objects that it can envoice. Such a reframed operatic reality might even lay claim to producing, on occasion, its own form of realism: as outlined above, Julien's serenade combines a particular relation to the material world with a particular use of its medium's representational conventions to convey a type of specifically operatic literalness. But this formulation risks returning once more to the diegetic performances in operas that have long offered safe haven to those who argue for opera's capacity, against all the odds, for realism. Worse, such a conclusion foregrounds the serenade's generic conventionality over the moment of dissolution - one that remains startling and, ultimately, more resistant to the very notion of diegesis. To examine the potential of such musical resistance, I need to turn to a second musical example, one that comes a few moments earlier in the opera.

\section{Machine}

When the curtain rose on the second tableau of Louise's Act 2 in February 1900, it revealed a workshop full of female labourers, carefully arrayed about the stage. As quoted earlier, they 'work while chattering - Some sing - One labourer works at a machine'. It is the last instruction that I want to consider now, and which I think can suggest more fully what opera (and music in general) may be able to offer our existing conceptions of realism. The music in this scene was particularly prone to be absorbed into comments about the opera's mise en scène rather than its musical potential - which is to say that it was particularly prone to going unheard. Lalo claimed it had 'almost no music: some dismantled music, some more or less pitched words'. ${ }^{61}$ La presse was more typical in referring briefly to the workshop scene as evidence of the new opera's 'magnificent or realist sets', marvelling: 'There is a couturier's workshop with a sewing machine! and it works!' 62 Like the 'real scissors' that Laloy imagined tourists admiring, Charpentier's Act 2 sewing machine was the real thing; and it was apparently novel enough still to earn a mention in an English-language guide to the opera published 12 years later. ${ }^{63}$ Nor was its presence limited to its onstage visual cue or operation: for large portions of the scene, it possesses its own stave in the orchestral score (see Example 1). The part is hardly sophisticated: continuous semiquavers in $6 / 8$, preempting by only a quaver beat the entry of the seamstresses, who 'la la' their way through an ascending $G$ major scale starting on $\hat{6}$. Small wonder this moment received

61 'Presque pas de musique, de la musique en poussière, de la parole notée à peu près'. Lalo, 'La musique', 2.

62 'Il y a aussi des décors magnifiques ou réalistes [...]; il y a un atelier de couturière avec une machine à coudre! et elle marche!' 'Intérim', 'Le théâtre', La presse, 4 February 1900, 3.

63 William H. Daly wrote of Act 2, scene ii: 'In this scene Charpentier has introduced a touch of realism, new, at least, in opera, by adding the noise of a sewing-machine to the medley of sounds produced by a room-full of girls, together with music in the street.' Daly, Charpentier's Louise (London: Alexander Moring, 1912), 49. 
Example 1 Charpentier, Louise, Act 2, second tableau, scene i, Figure 212, bars 1-9. Louise. By Gustave Charpentier. Copyright (C) 1900 Heugel. International Copyright Secured. All Rights Reserved. Printed by Permission of Hal Leonard Europe Ltd.

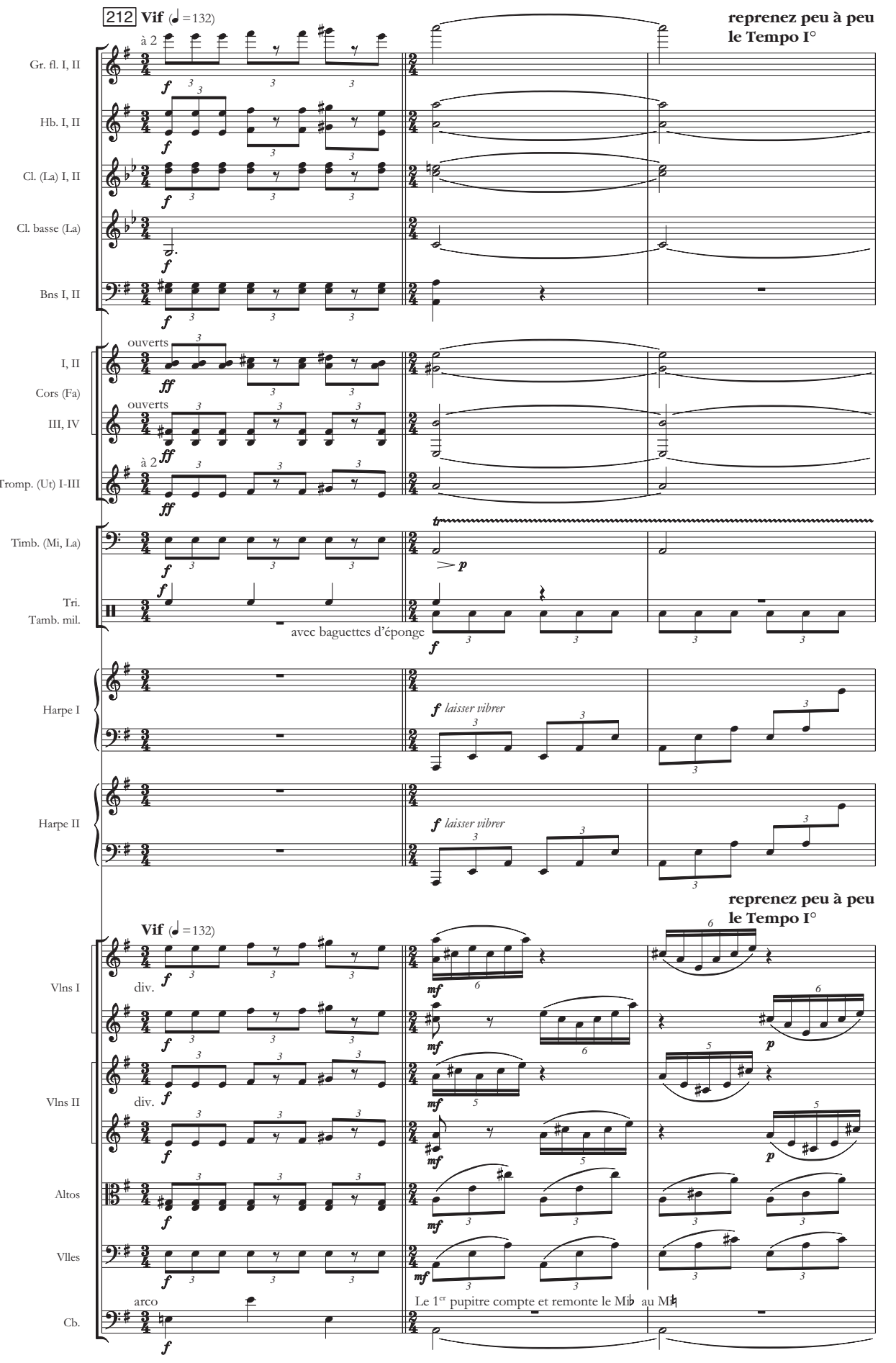


Example 1 (cont.)
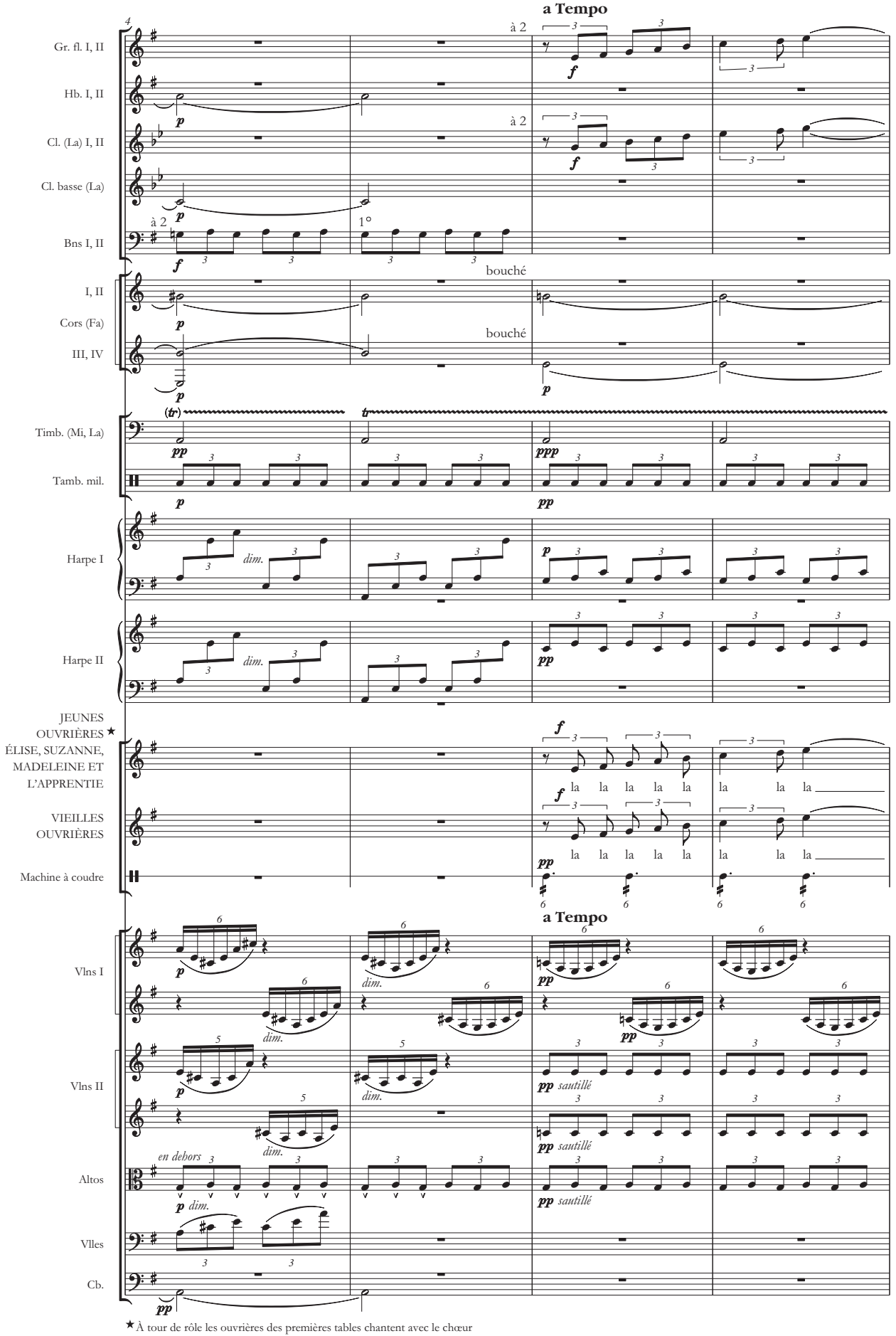
Example 1 (cont.)

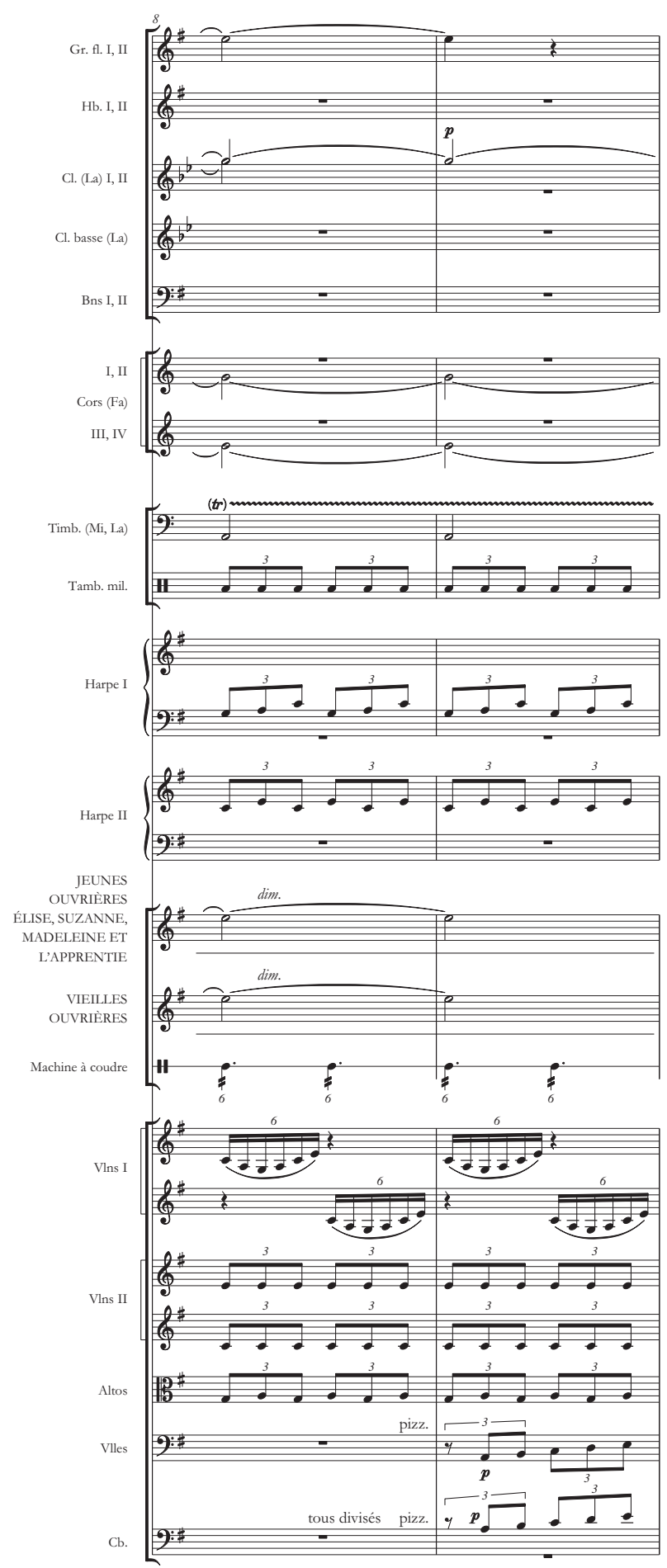


little attention as music in 1900 (and has attracted less since), as the score appears to be no more than a composing out of a basic stage direction. Some workers sing, one works at a machine.

But even this clearly diegetic passage - 'real-life music', if it is music at all - is fully embedded within the orchestral fabric. The 'literal' sound of the sewing machine finds orchestral amplification in the sautillé triplets of the second violins and violas, and in the same rhythm in the military drum (played with sponge-headed sticks). Perhaps more significantly, Charpentier provides these rhythmic effects with topical backup from the first violins, whose arpeggiated figure is surely modelled on the numerous musical sewing machines and spinning wheels depicted in earlier nineteenth-century songs and operas. ${ }^{64}$ Charpentier's sewing machine does not, then, sound simply as itself, an audible equivalent of those 'real scissors'. Rather, it participates in a more thoroughly orchestrated sewing-machine effect, contributing to a timbral combination that in turn entails the musicalization of the machine. Indeed, that musicalization gears up before the machine enters, as Charpentier has evoked this ultra-repetitive sound world - has already set his operatic sewing motif in motion - at the very start of the scene, with the arpeggiated 'sewing' figure in the violins. What is more, the military drum began its domesticated tattoo at the start of the preceding orchestral interlude, fully 138 bars earlier (see Example 2). The sewing machine itself is absent from the interlude; but the crisply articulated rhythm of the drum - as close to the timbre of a sewing machine's clack as any standard orchestral instrument could get - is again accompanied by sautillésecond violins and violas, again playing triplets. Meanwhile the harps' arpeggiated triplet figures prepare the way for the more obviously topical 'sewing' reference in the violins' later sextuplets. While Louise's very first audiences could not have known during this interlude that the curtain would shortly rise to reveal a sewing machine on stage, that moment of unveiling was surely important: the sewing machine appears as a physical manifestation of what has already been heard; an established convention of musical representation meets its catalyst and material index; two realities collide.

There is, though, more to unpack here. This musical foreshadowing of the sound of the sewing machine raises two important questions. The first relates to what the sewing machine is doing in Charpentier's score. Its onstage presence is evidently rooted in Carré's realist mise en scène; but why provide for its mechanical contribution to the score - or, to turn this around, why pre-empt a small sonic coup de théatre with longestablished (even old-fashioned) musical gestures that render the machine itself redundant? A second question concerns the relationship between Charpentier's two

64 Two particularly obvious examples might be Schubert's lied Gretchen am Spinnrade and the spinning chorus in Act 2 of Wagner's Der fliegende Holländer, both of which feature moto perpetuo effects: continuous semiquavers in a circular pattern in the piano part of the former; semiquaver and demisemiquaver agitations in the second violins and violas of the latter, punctuated by cello and bass pizzicatos that Thomas Grey identifies as depicting 'the rhythmic actions of the girls' feet on the treadles of their spinning-wheels'. For more on what Grey calls Wagner's 'inevitably descriptive accompaniment', see his 'Text, Action, and Music', Richard Wagner, Der fliegende Holländer, ed. Grey (Cambridge: Cambridge University Press, 2000), 36-64 (p. 48). 
Example 2 Charpentier, Louise, Act 2, interlude preceding second tableau, scene i, Figure 203, bars 1-4. Louise. By Gustave Charpentier. Copyright (C) 1900 Heugel. International Copyright Secured. All Rights Reserved. Printed by Permission of Hal Leonard Europe Ltd.

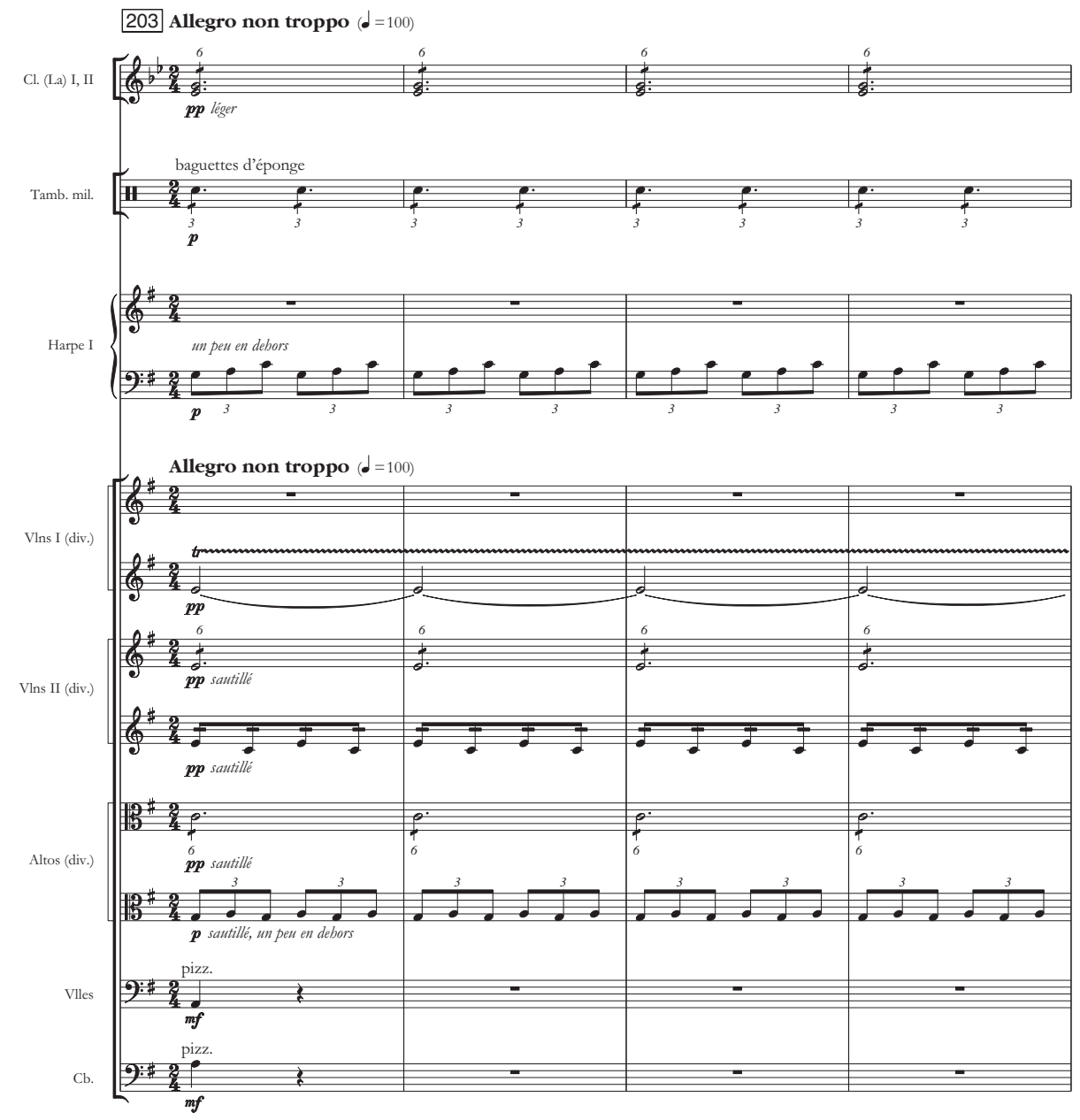

'hearings' of the sewing machine in this scene: ${ }^{65}$ within this operatic context, can one be heard as more real - or more 'realist' - than the other? And what is the significance of such doubled semantic labour; what might the apparent need for it suggest about opera's capacity for realism in 1900?

Perhaps here, at last, we approach an affordance particular to opera. Perhaps we can productively refigure the musical workings of realism in opera precisely around the slippage between 'realist' and 'realistic' that dominated critical discourse about Louise

65 I gesture here to Peter Szendy's conception of musical arrangement as a transcription of the act of hearing what is being arranged. Szendy, Listen: A History of our Ears, trans. Charlotte Mandell (New York: Fordham University Press, 2008). 
in 1900 and after. As should by now be clear, that same slippage is rendered audible in the scene outlined above. Charpentier's music was heard simultaneously as 'real music' and 'dismantled music' - as a lively, skilfully constructed musical tableau and a scene from which genuine music was absent. As such, his sewing machine encapsulates what separates music most decisively and provocatively from literature or visual art. Whereas Frye could label literary realism 'an art of implied simile' and Herbert sees in Courbet's late works the painter's 'predilection for matching world to canvas', Charpentier's doubly sounding sewing machine undermines any attempt to distinguish between representation and what is represented. The sewing machine sounds both as itself-like the bells in Act 3 of Tosca, which Arman Schwartz memorably describes as 'simply, stupidly, real' ${ }^{66}$ - and simultaneously as what is like itself. One could even say, thinking back to Frye and his demarcation of realism's similes and myth's metaphors, that music has no equivalent for those two figures of speech. Representation in music cannot differentiate between a sound that is like another sound and a sound that is being used, significantly, in the place of another sound - indeed, the representation in music of 'external' sounds will always entail both a listener's recognition of meaningful similarity and their willingness to derive significance from the distance opened up by the substitution of one sound for another.

To put this another way, operatic music (indeed, any music understood as in some way representational) can incorporate 'real' sounds alongside operatic ones: sounds such as the clacking of a sewing machine, no matter how rhythmically precise - not considered proper to the musical context in which they appear. Unlike Courbet's depiction in paint of aspects of the real world that already look like his artistic medium (with Frye's realist simile operating in reverse), Charpentier's sewing machine remains a sewing machine even when it is assigned its own musical stave and woven into the operatic fabric. Yet the fact that the composer incorporated the machine alongside a more conventional musical representation of its sound suggests that the materially 'real' was somehow insufficient, perhaps even inaudible in an operatic context. To repeat: Charpentier's orchestrally amplified machine sounds both as itself and as a representation of itself; a material artefact of the fin-de-siècle quotidian collides with the established conventions of representation and expression that constitute opera's own 'real world'.

\section{Afterlives}

Heard thus, it is just possible that Louise might, after all, satisfy one of the major demands made by Dahlhaus in his attempt to grapple with a mode of realism proper to nineteenth-century music in a book mentioned at the beginning of this article. In one of the finest moments in his problematic Realism in Nineteenth-Century Music, Dahlhaus insisted that, "What is decisive for the concept of realism is not the kind of reality alone - the street cry, the speech intonation, or the overpowering emotional expression undiluted by any stylization: it is also the form which shatters an aesthetic

66 Arman Schwartz, 'Rough Music: Tosca and Verismo Reconsidered', 19th-Century Music, 31 (2007-8), 228-44 (p. 234). 
norm for the sake of reality. ${ }^{67}$ There is little question that Charpentier's uncannily doubled sewing machine and his gradually disintegrating tenor serenade constitute some kind of stepping away from conventional operatic practice in 1900 - some kind of reaching beyond the operatic stage. Yet one can hardly claim that Charpentier's first opera sustains this unconventionality elsewhere, constituting the radical rebirth of opéra comique that a few of its more hopeful early critics implied. ${ }^{68}$ For commentators both in 1900 and more recently, Louise's score as a whole is too bound to operatic convention fully to merit the realist epithet. Even Emmanuel, we might recall, argued that although Louise offered 'admirable examples - perhaps the first real models, in the theatre - of real life in music, it is by no means an entirely realist work. Far from it: convention abounds in it' (see above, note 36).

As these and other comments like them make clear, the relationship between realism and conventionality is crucial, even while it is most often negatively defined. Indeed, Louise's basic conventionality and its consequent failure to attain the standards of aesthetic watershed expected by Dahlhaus make explicit realism's modernist credentials, both among music critics in 1900 and in recent humanities scholarship. There is little space in a putatively realist canon for more reactionary cultural products, for a realism that might also be regressive or even outmoded: realism, it seems, must turn on the twin axes of aesthetic novelty and revolution. It is all the more thought-provoking, then, that - as mentioned at the start of this article - by the time Louise was premièred in 1900, realism was no longer self-consciously cutting edge in either French literature or visual art. It was nearly half a century since Flaubert had weathered the storm whipped up by Madame Bovary; Zola published the first novel in his monumental Rougon-Macquart cycle in 1871; and Manet, whose Olympia had scandalized the 1865 Salon and who had subsequently been excluded from the 1867 Exposition Universelle, was awarded the Légion d'Honneur - that ultimate signifier of French institutional acceptance - in 1881, two years before his death.

In these circumstances it is hardly surprising that some of Charpentier's most persistent early detractors criticized his importation of realism into opera not only on the grounds of aesthetic incompatibility, but also because his attempt to be radical was so old-fashioned. As Lalo put it in Le temps: 'I regret that he remains attached - with a predilection fifteen years behind the times - to a form of art as dead as naturalism. ${ }^{6} 9$

67 Dahlhaus, Realism in Nineteenth-Century Music, 53.

68 Jane Fulcher describes Louise as 'far from a conventional opéra-comique: devoid of spoken dialogue, it relied rather on Wagnerian dramaturgy' - yet she also makes clear that in this very distance from 'conventional opéra-comique', Charpentier's opera was 'like many other works presented at the Opéracomique at the turn of the century'. Thus it was typical of its genre's current tendencies, if not its more venerable conventional markers. See Fulcher, 'Charpentier's Operatic "Roman musical”', 161. On the significance of Louise's relative conventionality, Huebner's reading of an interview given by Charpentier to Le Figaro in 1900 is helpful in clarifying the relationship between the composer's political stance and his musical language. He observes that Charpentier 'tied his defence of populist subject matter to his support of a relatively conservative musical style and long-standing efforts in France to bring opera to the people'. Huebner, 'Between Anarchism and the Box Office', 144.

69 'Je regrette plus encore qu'il demeure attaché, avec une predilection qui retarde de quinze ans, à une forme d'art aussi morte que la naturalisme.' Lalo, 'La musique', 1. 
Worse still, Lalo insisted that Louise's Act 2 bohemians were half a century out of date, emerging from what the critic identified as 'a mixture of Murger and Félix Pyat'. ${ }^{70} \mathrm{We}$ might also recall that bohemian Montmartre was largely non-existent by the time Louise was premièred: its avant-garde artistic scene - to which Charpentier was drawn in his youth - had largely moved elsewhere. Tourists arrived on the Butte in ever growing numbers. As in other bohemian-Paris operas written in the 1890s, the supposedly realist representation of the city in Louise was strongly marked by nostalgia; its strong sentimental undertone engaged an enormous, socially diverse audience over many decades in France. What is more, it is possible to trace in the opera's continued popularity into the mid-twentieth century a gradual easing of the tension between the real and the ideal, the two concepts that Bruneau had identified as fundamental to Charpentier's work. From the vantage point of 1931, for instance, one journalist was inspired by Louise to write at length about the changing 'sounds of the modern city': those of his own age were 'the sounds of the trams, the horns of buses and of cars'; those of Charpentier's were dominated by street cries - cries that, he marvelled, the composer had 'reproduced as precisely as possible'. ${ }^{71}$ In some sense, then, Louise appeared an ever more realistic portrayal of Paris in 1900 the further its audiences were removed from that time and place. By the early 1930s, the opera's nostalgic image of the fin-de-siècle city had become indistinguishable from a widely mythologized Parisian past reality.

None of this needs to detract from the ways in which Louise can still stimulate new ideas - can still disrupt our epistemological categories. Indeed, the opera's continued popularity and regular staging until the mid-twentieth century can suggest one final historiographical provocation. As it continued to be staged, broadcast on the radio and disseminated via gramophone recordings, Louise was repeatedly cut, modified and otherwise adjusted to suit changing circumstances. More often than not, Charpentier himself carried out these adaptations: his enthusiasm for creating technologically remediated versions of his only box-office hit was another manifestation of a rampant technophilia that led him to own no fewer than four radio sets. ${ }^{72}$ But one cut that was not authorized by Charpentier was apparently common during the First World War: the second tableau of Act 2 - that of the atelier, the sewing machine and the serenade was an operatic casualty of the need for shorter running times so that audiences could

70 'Un mélange de Murger et de Félix Pyat'. Ibid. Henry Murger was the author of Scènes de la vie de boheme, a set of stories set in Paris's Latin Quarter; they were initially serialized in the literary magazine Le corsaire and later published as a collection and adapted (with Théodore Barrière) into a play, La vie de la boheme. These stories subsequently formed the source texts for the two La bohème operas by Puccini (1896) and Leoncavallo (1897). Félix Pyat was a mid-century French socialist writer and politician.

71 'Le chef d'œuvre de Gustave Charpentier, où le compositeur reproduit d'une façon aussi précise que possible les cris de la rue au début de ce siècle [...] Malgré la disparition de la plupart des cris de la rue, les voies de la capitale ne sont pas devenues plus muettes: pour remplacer ces cris et ces appels, il y a les timbres des tramways.' Paul-Louis Hervier, 'Les bruits de la ville moderne', unidentified Toulouse newspaper, 15 January 1931. Clipping in BHVP, Fonds Gustave Charpentier, Dossier 24a.

72 See Michela Niccolai, 'Gustave Charpentier "producteur”: Regards d'un compositeur sur les nouveau médias', Revue de musicologie, 95 (2009), 449-74 (p. 452). 
return home on the final metro train. As a 'picturesque episode' ('épisode pittoresque'), André Himonet explained in his 1922 study, the scene could be cut without difficulty; the omission became 'almost mandatory' ('presque du règle'). ${ }^{73}$ In complete contrast to the proximity of Charpentier's street cries and the Paris of Louise's première imagined by one journalist in 1931, Himonet dismissed the passages in which I have attempted to uncover new possibilities for an operatic take on realism as merely picturesque - as ultimately dispensable in times of operatic encounter with the all-too-real exigencies of modern life.

73 Himonet, Louise de G. Charpentier, 94. 